\title{
TRANSPORT AND LOGISTICS TOWARDS ECONOMIC RESTRUCTURING IN BRAZIL
}

\author{
SILVEIRA, Marcio Rogerio ${ }^{\text {* }}$
}

(a) Doctor in Geography, Professor in Federal University of Santa Catarina (UFSC). ORCID ID: https://orcid.org/0000-0002-4451-0358. CURRICULUM LATTES: http://buscatextual.cnpq.br/buscatextual/visualizacv.do?id=K4760182T2

\section{(*) CORRESPONDING AUTHOR}

Address: UFSC, Departamento de Geociências, Campus Universitário da Trindade - Florianópolis - SC - Brasil. CEP: 88040-900. Tel: (+55 48) 37212627

E-mail: marcio.gedri@gmail.com

\begin{abstract}
The contemporary economic restructuring has two important components that articulated impact on the spatial reconfiguration in Brazilian territory: they are, the state logistics and corporate logistics focused on transportation and functioning as strategies for planning and management territorial (public) and corporative, with the purpose of inserting and expanding fluency, competitiveness and changing territorial configurations. The process of geographical expansion of capital count with the participation of the public power in the service of corporate demands for transport and infrastructure. In the same direction, the logistics held by companies optimizes engineering systems of transport and storage, to minimize new constructions and production costs. This study, therefore, has as scope to show that the logistics, as organizational innovation, serves to increase the fluidity and territorial competitiveness, interfering in the reordering of various spaces in the Brazilian territory.
\end{abstract}

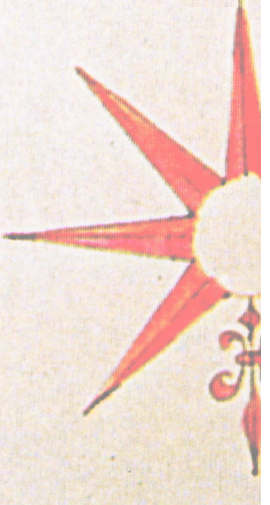

Keywords: Corporate logistics. State logistics. Territorial competitiveness. Territorial fluidity. Modernization. Standards and taxation systems.

\section{RESUMO / RESUMEN}

\section{TRANSPORTES E A LOGÍSTICA FRENTE À REESTRUTURAÇÃO ECONÔMICA NO} BRASIL

A contemporânea reestruturação econômica possui dois importantes componentes que articulados impactam na reconfiguração espacial que sofre o território brasileiro: são eles a logística de Estado e a logística corporativa voltadas para os transportes e funcionando como estratégias para o planejamento e para a gestão territorial (pública) e corporativa, com a finalidade de inserir e expandir a fluidez e a competitividade e alterar as configurações territoriais. Já os processos de expansão geográfica do capital contam com a atuação do poder público no atendimento das demandas corporativas por infraestruturas de transportes e armazenamento. Na mesma direção, a logística realizada pelas empresas, otimiza os sistemas de engenharia de transportes, a fim de minimizar novas construções e custos de produção. Este estudo mostra que a logística, enquanto inovação organizacional, serve para aumentar a fluidez e a competitividade territorial, interferindo no reordenamento de diversos espaços do território brasileiro.

Palavras-chave: Logística corporativa; Logística de Estado; Fluidez territorial; Competitividade territorial; Modernização; Sistemas de normas e tributação.

\section{TRANSPORTES Y LA LOGISTICA FRENTE A LA REESTRUCTURACION ECONÓMICA EN BRASIL}

La contemporánea reestructuración económica posee dos importantes componentes que articulados impactan en la reconfiguración espacial que sufre el territorio brasileño: son ellos la logística de Estado y la logística corporativa volcadas al transporte y funcionando como estrategias para la planificación y la gestión (público) y corporativa, con la finalidad de insertar y expandir la fluidez y la competitividad y alterar las configuraciones territoriales. Los procesos de expansión geográfica del capital cuentan con la actuación del poder público en la atención de las demandas corporativas por infraestructuras de transporte. En la misma dirección, la logística realizada por las empresas optimiza los sistemas de ingeniería de transporte y de almacenamiento a fin de minimizar nuevas construcciones y costos de producción. La investigación, tiene como objetivo mostrar que la logística, como innovación organizacional, sirve para aumentar la fluidez y la competitividad territorial, interfiriendo en el reordenamiento de diversos espacios del territorio brasileño.

Palabras clave: Logística corporativa; Logística de Estado; Fluidez territorial; Competitividad territorial; Modernización; Sistemas de normas y tributación. 


\section{INTRODUCTION}

There was in Brazil, from 1991, with the economic opening, a significant change in the volume of the circulation of goods, capitals and information. A more intensive economic flow (circulation of product input) stemmed notably as of 2003, with the Lula da Silva government, because of the economic policy aimed at the extension of the internal market, the growth of exportations of agro industrial products (grains and meats), minerals and the importation of influxes and finished products. China enters more aggressively into this scenario as the commercial partner of Brazil, substituting the United States as main commercial partner. There was shaped, in this way, an inequitable extension of the circulation of goods with regards to planning and construction of infrastructures of transport and storage of goods. This fact was one of the reasons for several analysts and economical planners to allege a supposed "logistics blackout" (to the model which there was in the energy sector during the government of Fernando Henrique Cardoso). These professionals yet alleged, that to avoid the "logistic blackout", or more exactly, an "infrastructural blackout", the public authorities should decelerate the economy, since the infrastructures, overall, would not keep pace with the growth of the economy. This was a theory defended even by members of Lula da Silva government.

However, the "logistics blackout" never took place - despite there being throughout the Brazilian territory clear choking points of the infrastructures - and the engineering systems withstood the circulation increase of goods, people (with the increase of the income, the number of private car decreased vertiginously) as to information (enlargement of optic fiber networks, satellites and mobile telecommunication). In this context, which are the reasons for the infrastructures being able to withstand the demands of transport in storage in a relatively short time? And what are the consequences of this increase on fluidity, in that which regards the production of space in the national territory? The article also aims to contribute, through a critical and analytical method, to studies that aspire to decipher the territorial reconfigurations in Brazil caused by public and corporate transport and logistics policies.

It is known that in the economic policy of the Lula da Silva Government and the heating of the global economy that Brazil increased its GDP (Gross Domestic Product). These two coefficients are directly related, in a cause and effect interaction, with the addition of the expansion of goods throughout the national territory. However, it is not presumable, during this same period of time, the State develop the needed infrastructures to answer these new corporate and consumer suits, because the time of the economy and dynamization of the national GDP (faster) is, despite being related, different from the time of the planning and the execution of the infrastructures (slower). In this scenario, the question is: how did Brazil grow economically during consecutive years without going through "an infrastructural blackout" which would upset the fluidity and the territorial competitiveness of the country? Some reasons will be discussed such as: 1) the exponential capability to use the organizational and technical innovations - like the "corporative logistics" and the technical progress in the transport - effected by the companies, in order to optimize the existent infrastructures; 2) the capability of the State, by means of the "logistics of the State," the increase of the territorial fluidity, improving the planning of the circulation in the territory to selected the corporative litigations.

The use of the corporative logistics (with the adoption of optimatization strategies of processes and costs of transport and storage) among the companies seated in the country was increased in the beginning of the 1990s and, especially, with the increase of the competitiveness received by the Lula da Silva government. The purpose of this improvement was offer advancements in the strategies, in the planning and in the management of transports in an entrepreneurial ambience. But, that movement happened in a direct relation with the State logistics (strategy, planning and management of public authorities in the provision of greater territorial fluidity), expanding the efficiency in the 
movement of goods, in the economic fluxes and consequently, the spatial interactions. ${ }^{1}$ Bearing in mind that the corporative logistics, while haunting the optimization of the costs of transport and storage, equally, seeks to maximize the transport systems (objects and actions of the transports), giving them greater efficiency and movement through the transport means, without the imperative implementation of the new circulation infrastructures.

The State role, from public policies, was aimed: 1) the construction and improvement of the infrastructures in strategic knots of the national circulation network, such as drag harbor channels, tunnels, bridges, boundaries and roads duplications and others; 2) the construction of new strategic infrastructures (harbors, highways, Dry Docks, railroads and others) able to change the old spatial logic of regional circulation (concentrated in the Southwest and the South) to another, a bit more decentralized, with public and private resources or public-private (public-private partnerships) are directed; 3) the formulation and implementation of the system of norms and taxing (systems of actions and production relationship), with the objective of debureaucratization of moving of goods (importation/exportation and internal circulation), mitigate and standardize taxes and fees. All those elements of the "logistics of the State" moved and softening the direction of total circulation costs of capital by means on territorial fluidity.

Finally, our intention is to contribute theoretically and expeditiously to analyze some facts contained in the Brazilian territory, arrogated to circulation, to transport and to the logistics, responsible for the foremost territorial alterations; in that which regards changes to economic fluxes, to fluidity, to territorial competitiveness and by implication, to the due spatial interactions. For a satisfactory result, it is also necessary to more profoundly understand some components attributed to the changes in the transport systems, such as: 1) The technical innovations in the means and ways of transports; 2) The organizational innovations, such as logistics; 3) The construction of infrastructures in knots or lines of the national transport network; 4) The deregulations and new regulations (guidelines); and 5) The tributary transformations. The advancement of the international productive forces and reallocations in diverse national produced variations in the production relations, which, therefore, affected the territorial division of labor hitherto valid. With this, the intensity of the circulation of capital, the fruit of the geographical expansions of capitals, was vastly revolutionized. Circulation, in a generalized form, is no longer currently done as it was in the past.

\section{METHOD, THEORETICAL DEVELOPMENT AND RELEVANCE OF CIRCULATION, TRANSPORTATION AND LOGISTICS BEFORE THE RECENT ECONOMIC RESTRUCTURINGS}

Man, as a social being, upon interacting with nature and with other men does so in society and consequently, produces space. It is in this sense, that the space as known by geographers, slimly loses its natural predicate and gains the admirable role of social instance (second nature). For that reason, space is a totality (complexes of complexes) packed with complex consignations, largely,

(1) The spatial interactions, according to a dialectic-materialistic focus, refers to the notion which refer, in the conscience, the dialectic relation between contradictory material formations and derive from the philosophical category of interaction or reciprocal action. That dialectic relation has as result a synthesis, a transformation, or the ignition of a new process of development. Therefore, the spatial interactions involve, transport, mobility and accessibility - which are categories which possess a spatial dimensionl without the dialectic cannot occur between the referred material formations, like, for example, capital and labor, the subject and object of knowledge, amongst others, which demand some type of mobility and are socially constructed on different geographical scales (COCCO; SILVEIRA, 2011). 
intermediated by social interactions. Those, in a certain measure, only cooperate with the production of space, if it has circulation (movement, transportation, mobility) and storage, as well the forms of planning and management, among others. Such continuous processes become each time more complex, according to the human group turning away from primitive communism and turning to more "advanced" relations of the capitalist production mode (SILVEIRA, 2014). These, right away, have together with human evolution, a spatial component, that is, the spatial interactions, the territorial formation and territorialities. There appear, thus, the crucial elements o four interpretations, that is: transport, logistics and, later, the State as the regulator of both, but which also makes use of them to produce space.

Men, upon moving in space, transport and store, because both actions are geographical determinants of production. The production only comes through labor, for this is the founding category of the social relations and the only one capable to establish, at the same time, an intermediation between men and nature. Transports have a direct relationship with the general production (production of human existence in relationship with nature). In that way, if there is production, there is transferal, of moving, of mobility, of storage and of logistics (from the simplest forms to the most complex ones). The systems of transportation and storage are the general conditions of compelling production to human existence, since they are crucial auxiliaries for human groups to withdraw from nature their means of subsistence. Besides, they are also means of production for social life.

Since production is a collective need, there are two of their fundamental and auxiliary archetypes, that is: logistics, as strategy, and the planning of transportation and storage, which in large measure, is thought out by the corporations (corporative logistics). These components can be explained in the following way: the act of the State in developing strategies, planning and managing the fluidity and the territorial competitiveness (logistics of the State), through diverses actions, such as standardization and taxation, besides concretely realizing engineering systems which make them viable; and transport in itself, to move (change of space by human groups or individuals) and, at a given historical moment, of saving the means of subsistence (storage). Factors, consequently, related to spatial interactions and, thus, related to the production of space.

Transport, storage and their planning are basic for the achievement of goods by means of consumption and, consequently, for the generation of the demand of production (cyclic movement production, distribution, exchange and consumption), which, increasingly specializes and perfects. Such features are greatly developed in capitalism. Human activities are conscious. Everything which men do is schematized, for they try to foresee the results of their action, though these do not precisely express their objectivizations. In this sense, if logistics is strategy, planning and management of transportation and storage, it has been present since the emancipation of man, since these activities are in the heart of that process, having logistics as an important abstraction. Man only established himself, among other factors, as such, on moving in space (hunting and harvest), upon transporting his livelihood (hunting and harvest) and, subsequently, when exchanging his surplus and accumulating capital. All of this covers the act of transport and that only happens with a strategy, a planning, an objectivization. The same applies for the different forms of storage constituted ontologically.

In the same form as, salaried labor and the machinery were employed, logistics was employed, perfected, intensified in the armed forces before being vastly incorporated by the bourgeois society. This last phase, that is, logistics as an important activity in the mode of capitalist production, especially with the advent of the big industry, is the logistics we call corporative logistics, above all, upon checking that it became a constitutional determination for the advancement of the productive forces and for the restructuring of the relations of production in the most recent practice of capitalism, or better yet, in the so-called "capital empire" (WOOD, 2014).

Therefore, the theoretical benchmark which guides the current article involves several theorists of capitalism (Marx, 2011a, 2011b, Cheptulin, 1982, Chesnais, 1996, Chandler, 1998, Harvey, 
1992, 2006, Porter, 1986, Santos, 1996, 2001, Wood, 2014, Arrighi, 1996, Belluzzo, 2013 and others) and scholars on circulation, transport and logistics (Castillo, 2001, Silveira, 2011, 2013, 2014, Santos and Silveira, 2008, Monié and Silva, 2003, Felipe, Junior, 2014, Barat, 2007, and others) to arrive at an abstractive capable of validating these elements, as essential to the recent world and Brazilian economic restructuring. Our research further proposes organizing and applying the theoretical benchmark capable of cooperating with the understanding of the territorial changes in certain territories of Brazil, namely, those impacted by the logistics of the State and with the corporative in the provision of greater fluidity and territorial competitiveness. The productive forces, thereby, progress like an indigence of the intercapitalist competition, therefore, affect spatial configurations and reconfigurations. The most dynamic in terms of infrastructures are those most affected and begin to show a greater economic fluidity. Therefore, the territoriality is affected, and the hierarchy of power places the economic event as prominent. At the same time, contradictions between the productive forces and the relation of production begin to become intense, for dynamically institutional changes are slower and, concomitantly, key for the capitalist accumulation. It is due to those facts that in Brazil not only the enlargement of the infrastructures of transportation is important for the productive restructuring, but also the normative and tributary changes are crucial for untie institutional knots which do not fulfill the advancement of the productive forces demanded by the corporations. Institutional alterations (normative and tributary) are implemented, whilst the different territories, in different scales, are submitted a several contradictions.

Economic restructuring changes the pre-established territorial organization and new spatial reconfigurations arise from direct foreign investment, the expansion of the tertiary sector (KON, 2004), the valuation of circulation and the new patterns related to economic flows and spatial interactions. New archetypes of economic localization are imposed on large-scale sites alongside networks and corporations. Concomitantly bankruptcies, mergers and acquisitions are related to speculative foreign investments and capital flight. Thus, in the face of the selective power of capital, the most fluid and territorially competitive spaces are defined. The state, devoid of investment capacity, begins a process of dismantling the system of existing regulations and taxation, gaining, in view of this, competitive advantages for corporations, managing counterclaims between national and foreign capitalist competitors. At certain moments, capitalist competition enters a more aggressive stage, impacting mainly local capitals and, with it, the capital-labor relationship and the class struggle are also redefined. The territorial division of labor as a reflection of these features changes, for it establishes new logics for expansion and for the geographical mobility of capital, wich transport, storage and logistics are the key.

\section{THE SYSTEMS OF CIRCULATION, TRANSPORTATION AND LOGISTICS IN FACE OF RECENT GEOECONOMIC TRANSFORMATIONS IN THE WORLD AND IN BRAZIL}

The advent of the economic restructuring in the world ambience and, more recently, in Brazil, needed changes in the production and in the patterns of consumption, like: outsourcing by way of production unbundling spatially diverse; the expansion of the territorial division of labor; the predominance of incremental innovations; the flexibilization of labor relations; the addition of outsourcing; and others. Facts that are directly related to the expansion of the circulation of capital and especially to the spread of financial speculation. 
The concentration and centralization of capital through direct and speculative investments has in base the exploitation of labor, that is, the surplus-value withdrawn from production, of the activities which produce value, whether they are tangible (furniture, automobiles, computers, clothes, shoes and others) or untangible (theater, music, higher services, such as logistics and others). Even though that production is presently hostage of a completely financial system and turning production hostage, this is, the base of the generation of wealth. This, in turn, is still in transformation, in the materiality of the goods, though it is intangível and thats circulation occurs by ways completely/ relatively different from a traditional mobile good. This implies, in one form or another, the existence of a growing movement on the global scale of goods and Money as a flux of payment of all that movement. It is important to empasize that on the global scale of goods - it was estimated by UNCTAD (United Nations Conference on Commerce and Development) which, in the middle of the decade of $1990,1 / 3$ of the international trade was the fruit of the relation among the companies of the same group, $1 / 3$ of the same sector and $1 / 3$ of the finished product, that is, the input circulated twice as much as finished products, and that movement of inputs continue. However, in order for this to occur, the flexibilization and standardization in the systems of norms and taxation were necessary, in addition to a revolution in the systems of transportation, storage and logistics, that is, a logistics revolution, with the objective of lowering costs and enlarging the circulation of capital.

It can be observed that the dynamization of the market was more significant than in the countries which, up until then, were out of the traditional patterns of the (Welfare State), with special mention of countries such as China, India, South Africa, Brazil and Eastern European countries. In these places, the capitalist market takes on a dimension, for the first time, on a broad scale, ${ }^{2}$ notably, in regard to the commercial, political, tributary, regulatory and circulation of financial capital, with prominence for the speculative. These facts remit to the need for decrease of costs with transport, storage and logistics by enlargement of the infrastructures, Technical progress of the means and ways of transport, standardization of norms and lower taxation expenses, besides the extensive collaboration of national and local governments, by means of a public policy dimension. The same dynamic is observed in the intensification of the circulation of information and capitals. That is the reason of the recent transformations in the global are classified by Chesnais (1996), as the globalization of the capital; and by Ellen Wood (2014), the empire of capital. Only by means of all that was it possible, among other things, to verify the development of productive chains and the constitution of extensive global of values (extensive international chains of supply, production and distribution).

The current logistic revolution to be able to concretize and contribute with the recent "economic order" lacked a series of elements in constant interaction, such as:

1) demands for economic fluxes on a global scale, a large and intense commercial pattern allowed by the opening of national economies;

2) technical innovations in the means and ways of transportation as an aid for the cooling of movement costs, such as the increase of transportation of cargo by transportation vehicle (in weight and amount), lower maintenance and optimized ways for faster, speedier and secure routes (such as highways duplicated in the autobans style, such as Castelo Branco, in the state of São Paulo);

3) organizational innovations related to the strategies, planning and management of transportation and storage, that is, a modern logistics realized by the companies;

(2) We corroborate with Santos (2001) and Hirst Thompson (1999), when reporting that "globalization" in the past was spatially as large as currently. However, we can mention current features: the intensity and ease of circulation due, especially, to communication factors. 
4) a system of norms and taxation which facilitates transactions between those responsible for the origin, for the movement (in large measure multimodal operators) and by the consignee of the cargo;

5) an information technology system that accurately establishes the movement of cargo and information for its safety (cargo control and tracking);

6) an international financial system (standardized and low cost) that enables the payment of freight and goods of goods negotiated instantly (only possible with the extension of information technology and standardization of the norms of financial movement).

Brazil, in 2003, with the government of Luiz Lula da Silva, was one of the substantial countries that restored economy, expanding insertion in the relations and international trade and (with emphasis on agribusiness and mineral commodities), in addition to extending and intensifying internal market, especially, for the importation of outputs and goods. On the other hand, there is a fact that precedes the geoeconomic changes of the first decades of the XXI century in Brazil, that is, those occurred in the decade of the 1990s, with the most abrupt opening of the economy during an economic crisis. During this period, most of the national companies were indebted and in a process of productive restructuring, in addition to being accustomed to the reserve of the market (which also favored the foreign multinationals installed in the country). The relative reservation of the national market to the national producers was able to maintain an incredible preoccupation with regard to production costs (for some companies that were not linked to the national market and, therefore, did not suffer external competition and that were oligopolistic and monopolistic) and did not stimulate the search for technical and organizational innovation to optimize and increase the efficiency the transportation and storage.

The companies, therefore, with productive units in the national territory suffered a rapid and strong competition of the transnational companies, with a chain of mergers, acquisitions and bankruptcies One of the handicaps before the TNC's (transnational corporations) were the higher costs related to the chains of supply, production and distribution. In part, they were fruit: of an infraestrutural system of transportation and deficient storage and an archain logistics, in addition to an old fleet; of the high fuel costs; of an unbalanced transport matrix; of a complex, bureaucratic and expensive tax and regulatory system. The primitive logistics of the companies and of the State made the national companies less competitive (in efficiency, deadlines, security and insurance prices, time, loss of cargoes and, finally, resulting in circulation costs) before the transnational both in the internal market as well as its connection with the external market.

This set of events changed the organization of the Brazilian space, it changed the territory to satisfy the litigations of the great capital avid to modernize, the selected territories, according to its own interest. Demanded in those spaces an also selected territorial fluidity and the largest agent in the consolidation of these new fluid spatial forms was the State (in diverse scales) that, through public policies, practiced a logistics, a territorial ordering, with the view of meeting the national trade interests and foreign, such as plants (supplies for automobiles, electro-electronics, telephony and others) which serve the national market and which also export throughout the Brazilian territory (see the case of transnational companies along the Castelo Branco, Anhanguera, Bandeirantes and Presidente Dutra highways, in the State of São Paulo). Moreover, in this level, there are a number of national trade companies and, especially foreign importers, beyond the diverse sector of services, such as transportation and storage.

The current global economic organization incorporated, consecutively, new productive and consumer spaces, besides the modernization of some of the traditional territories. There took place, thus, the generation of new economic fluxes, of population mobility, of public and private 
investments, id est, regarding the spatial interactions were notably enlarged. The most recent dynamization of the Brazilian economy is the product of the international trade expansion and of the new independent external policy (extroverted) that, together with certain public policies, stirred the national market. Thus, new territorial configurations ensued which are imbued with greater fluidity and apt for competitiveness.

The incorporation of new territories into the international economy, inclusive the Brazilian one, only occurred due to a greater viability/facility/flexibility of the factors of production (land, capital and work). The work, of the corporative lawsuits, which seek a greater territorial fluidity in order to facilitate the traditional factors of spatial location. Besides enhancing goods and capitals in the territory, respecting transnational demands for competitiveness, seeking a greater accumulation of capital, is a factual objective. None of this occurs without a global logistics control revolution, set in a context of techno-scientific and information technology ambience (SANTOS, 1996), with acute reverberation in the country. The current position of capitalism was only achieved, and if it adolesces rapidly, through the eloquent technological and organizational innovations in both the transportation and storage system as well as in the systems of standards, taxation and, in particular logistics. The cooling of transportation and storage costs, in the valence of the increase inter-capitalist competition and exploitation of labor, started to be one of the most elementary competitive strategies of the companies to the consolidation the search of presumed markets.

Transferring more rapidly over long distances, safeguarding or valuing the goods, is a "prize" that corporations try to seize to raise their competitive bases. The relativization of distance," with lower costs for the movement of goods and capitals, is central to the current stage of capitalism, which is territorially more intense and widespread than in previous stages. In the meantime, the national, federative and local states, are set out in the quest to provide their territories with satisfactory engineering systems to increase territorial fluidity in the eminence of becoming more competitive, defining their spaces as receivers of large corporations, so to speak, afflict the preexisting territorialities. The State of Santa Catarina and several of its cities are recent examples of this process. For some time, the governments - by means of fiscal wars (such as ICMS - Tax on Circulation of Goods and Services and ISS - Tax on services, through Prodec ${ }^{3}$ and Pró-Emprego ${ }^{4}$ Programs) and expansion of engineering systems (port modernization, expansion and maintenance of highways) - attracted foreign companies, like General Motors, BMW, Perini and others. Another factor is that state governments and, notably, that of Santa Catarina, began to adopt a policy of international relations called "paradiplomacy". It aims to carry out business contacts directly with foreign governments and companies, without the intermediation of Itamarati and, therefore, with little presence of the Federal Government. This "paradiplomacy", with business intentions, is direct in search of FDI (Foreign Direct Investments). In the case of the Santa Catarina State, there is, also, Invest SC (Investment Appeals Agency) which has the objective of attracting and facilitating investments and boosting the economic development of the state (FIESC, 2017). Public authorities therefore create favorable conditions for attracting FDI, through transportation infrastructures (highways, harbors, airports) and storage and a system of normatization and taxation for circulation.

By developing the territory with the purpose of attending corporative litigations, in relation to logistics, the State adheres to "State logistics" turned, with greater end, to business interests. Such an event intensifies the emulation among territories to attract industrial companies, of retail and of services, guiding the dylation of outsourcing, without a totalizing planning. The economi-

(3) The Program of Development of the Santa Catarina Company (PRODEC) aims to Grant incentives to the implantation or the expansion of industrial companies, which came to produce and generate jobs and income in the State of Santa Catarina (SANTA CATARINA, 2017)

(4) It has the objective of generating employment and income through tax treatment different from ICMS (SANTA CATARINA, 2017). 
cal restructurings which occurred in Brazil conferred specializations to the territories (between management and production) capable of veneering the same unequally with engineering systems, services, labor and inputs. A "shortsighted" vision, more in keeping with the expansion of global competitiveness and contemporary capitalist accumulation phase, in which Brazil enters unequally, but in an accepted way.

Brazil, in this scenario, went through unsurmountable changes in the transportation, storage and logistic systems starting: 1) by the concessions of public services to the private initiative; 2) through the introduction of a modern logistics and technical progress, both allowed by the opening of the national companies to national capital through a process of denationalization of the Brazilian economy, with mergers, acquisitions and bankruptcies; 3 ) the adjustment of the national firms to a more competitive transportation, storage and logistics archetype; and 4) by the role of the State in the providing infrastructures, in the adjustment of standards, norms, taxation and territorial planning instruments ${ }^{5}$ aimed at corporate fluidity.

Therefore, today's economic restructuring, the implication of the "globalization of capital" and/or "empire of capital", affects the Brazilian economy. It has a "relatively new" and more articulate device, that is, a corporate logistics and a state logistics, which make possible a significant fluidity and territorial competitiveness to the point of reordering/reorganizing respectable portions of the Brazilian territory. Thus, there is an intrinsic correlation between the "logistics of the State" and the "corporate logistics" and together, articulated, they selectively influence, the increase of the fluidity and the territorial competitiveness in clear portions of Brazil to the detriment of other spaces, especially, always through corporate predilections. That is, when the public authority is more stimulated to attend large business instances by engineering systems, and when companies, through corporate logistics, optimize existing infrastructures to fill the lack of transportation and storage infrastructures. Faced with this context, the facts lead to collisions in the territorial organization, enlarging in some spaces the regional inequalities.

Prior to Brazil's more competitive insertion in international trade and the expansion of the internal market, transportation, storage, logistics, standards, and tributacion systems were disjointed and insufficient, importing a narrow territorial fluidity and competitiveness, which are more provincial and diverse than at present. The desopression of these systems, as a reflection of the new form of capitalist accumulation, lengthened the competitiveness between the corporations and, later, between the territories, interfering in the Brazilian territorial dynamics with the objective of affecting the correlations of forces between them, creating new territorialities and impelling a territorial rearrangement channeled to corporate business.

Thus, both state logistics, in the provision of transport, engineering, standards and taxation systems, and corporate logistics optimize transport, storage and logistics services (customs, cargo consolidation, merchandise handling, packaging, among others). These elements are present in the recent economic restructuring in Brazil and potentiate the most competitive regions in support of the current needs of external and internal markets. One example is the public policies of the federal, state and municipal governments (infrastructures, concessions, tax benefits and others) and, in a consecutive way, the know-how in transport, storage and logistics services coined corporately in the port and logistics complex of Itajaí/Navegantes, turning it into national prominence, culminating a new feature in a harbor region that, in the 1990s, was typically depressed.

(5) Infrastructure planning bodies were dismantled or scrapped, specifically from the 1990s. Since then, regulatory agencies have prevailed. They act, for the most part, disconnected from state interests. Therefore, planning has become more sectorial, private and, consequently, serving political and corporate demands (SILVEIRA, 2014). 
On the other hand, the planning and implementation of transport systems, logistics, norms and taxation can cooperate for a more balanced territorial reorganization, that is, state logistics that induces development in a way that alleviates existing regional inequalities. State and corporate logistics are prominent in the geoeconomic rearrangement of the Brazilian territory, since they emphasize a current fluidity and territorial competitiveness.

\section{ECONOMIC OPENNESS, INTERNATIONAL INSERTION AND ASPECTS OF TERRITORIAL REORGANIZATION IN BRAZIL}

In order, for the circulation of capital to take place, it is usual to have both the planning and management of transportation (transport logistics) and the physical movement of goods from a place of production to a place of consumption, and it is the transport that provides this. Therefore, it is fundamental to create certain conditions for the expansion of the circulation of capital (development of capitalism), and therefore, economic and territorial restructuring is paramount (change is continuous because it is a crucial aspect of the movement). It is a fact that the various producers of the space, among them, stand out the State and the private initiative, being expressed more concretely by the amplification of the infrastructures of transport; of development and use of transportation technology (information technology and technical progress and the transportation ways and means); in the regulations and taxations for transportation; of storage; and logistics systems. With these instruments, territories that meet the imperatives of capitalist expansion are conceived and restructured. Territorialities are shaping.

Transport costs are on the final price of the product, since they are actual production costs in the whole circulation chain - supply, production and distribution (MARX, 2011a). The cooling of circulation costs, via technological and organizational innovations, is an effect of increasing labor productivity, because when performing the activity performed by the worker more efficiently, quickly and accurately, the machine (more efficient truck or a forklift replacing a stevedore or "plate") adds the amount of hours not paid to the worker and, consequently, the translated product is depreciated. ${ }^{6}$ In addition to innovations in (organizational) processes and (techniques) products that are fundamental to the development of productive forces and large-scale (CHANDLER, 1998) accumulation of capital, create concrete conditions for overcoming spatial barriers, leading to geographical expansions of capital.

New spaces are included while selectively, consumer markets and usual producers are energized. Brazil has experienced this in two recent periods: with the economic opening of the 1990s, with the governments of Fernando Collor de Mello and Fernando Henrique Cardoso, and with the expansion of international trade and the heating of the domestic market, after 2003.

Circulation costs are attenuated due to the development of technological and organizational innovations applied to means of transportation and storage, but above all, due to the public investments in infrastructures and the flexibilization of the tax and regulatory system it should be remembered that the prices of raw materials and other goods are sensitive to transport liabilities. A fact spatially loosens the relations of exchange, that is to say, the geographical extension of capital (SILVEIRA, 2014). The costs of circulation are reduced by the improvement of transport, as this impinges on more affordable prices, makes the movement of goods faster and, therefore, the

(6) In addition to increasing the storage of the product by means of a suitable packaging, a truck, a wagon, among other means of transport, which have high technology and logistics, also shorten the delivery time of the merchandise and, thus, increase the time of exposure of the product for sale, especially those with a short term. Finally, they are factors that increase or preserve the value of the commodity and, therefore, increase the profit and make the capitalist, who "lays hand" of these technologies, more competitive. This widens, in this way, intercapitalist competition. 
circulation becomes more efficient. The cheapening of many elements of constant capital, coupled with the increase in the exploitation of variable capital, induces the expansion of the geographic market. In this process, there are intense socio-spatial changes and the social changes are also due to this process of interaction between territory and society. This is why circulation is a phenomenon strictly geographical and strongly linked to the circulatory movement of capital. With production based more and more on exchange value - with the expansion of exchanges and spatial scales for its realization - the physical conditions of the exchanges are fundamental for circulation costs. Consistent physical conjunctions for trade are created by capital. The overthrow of geographical barriers does not depend only on simple restructurings in political, economic and productive relations, but also on investments in transport and telecommunications, which are articulated to the evolution of planning and management in the media, regulations and taxation on various scales, including supranational ones (see the case of IIRSA/COSIPLAN). The quest for capitalism by reducing circulation expenditures is not only to heighten the relations of exchange between already consolidated economic and population spaces, but it also serves to conceive and manage new territories for accumulation. Event only franked through the reduction of communication costs, among them are transport. An example occurs in the interior of Brazil, mainly in the Midwest, West of Bahia and North, where cities such as Dourados/MS, Sorriso/MT, Porto Nacional/TO, Santana do Araguaia/ PA, Luiz Eduardo Magalhães/BA and Barreiras/BA, stand to grant the expansion of agribusiness. Cities that, in addition to production, function to advise the soybean and livestock production chain, creating infrastructural and superstructural conditions, through the provision of housing, medical assistance, school, safety, among others, mainly serve as a logistics node for a national and international transport network for grain and meat disposal. Such fluidity has undergone a process of decentralization with the opening of highways, railroads, waterways, river and maritime harbors in the interior of Brazil, forming export corridors. However, the concentration still remains in the harbors of Southeast and South of Brazil (Santos and Paranaguá harbors, for example) (FELIPE JUNIOR, 2014). This dynamics in the interior of Brazil would be impracticable without the general conditions of production, without technical and organizational innovations in the transportation, storage systems and logistics services. In addition, of course, the factors of production (land, labor, capital, including technology, all these aspects are related to agribusiness).

All these elements cited are in interaction for the expansion of the territorial competitiveness of several spaces of the Midwest, North and Northeast of Brazil. One territory has difficulty competing with another if the means required for this are not put into practice. It is not possible to explore, to transform nature through work, if certain areas of the Brazilian territory are not prepared for production, that is, engineering systems suitable for the practice of fluidity. It is very costly to transport inputs, to produce and distribute goods by dirt road, if in addition, the basic foreign competitors of Brazil transport with lower costs, by modern railways and waterways. Also, the infrastructures; logistics; standards and taxation systems; the cost of inputs and labor; the productivity of labor, among other elements are peremptory for the competitiveness, especially, the territorial. Under unequal conditions, transport means become cheaper or more expensive and are important elements of competitiveness. But these unequal conditions, still very common, refer to a range of factors that involve transport, logistics and storage. In other words, this means that traveling with a truck on a poorly maintained highway can be advantageous if the freelance or business carrier has a logistics that points to the prohibition of queues, tolls and the greater relativization of distance, finally, to make this route more efficient, more competitive than another. The distance with its striking characteristic of relativity is only possible thanks to an essential factor, id est, "time". And the latter, with regard to a short course, is conditioned, as reported by technological and organizational innovations, by investments, by standards, by tariffs, by infrastructures, by corporate logistics and by other coefficients in line with circulation. 
Likewise, the need to expand the process of accumulation, by reducing circulation costs (via time of rotation), promotes the agglomeration of production in some metropolitan/urban centers, and in the same way stimulates constant economic restructuring through deconcentration and productive and consumption reconcentrations. The level of complexity to reach the optimum of economic location (industrial, commercial and service) increases, consecutively, overcoming, in certain aspects, the traditional factors of location. Territory is affected, reconfigured and new territorialities arise as a product of geographic mobility of capital based on global corporate demands. Territorial planning, until then imperfect, is redirected to increase territorial fluidity. The State, in many circumstances, proceeds, through State logistics, to a territorial logistics directed to corporeal corporations, via motorways, tollroads, railroad export lobby, among others. Habitual episode in the Macrometropole Paulista (EMPLASA, 2015) for decades (strong increase of the tolls), but from the Lula da Silva government, the most deconcentrated (and somewhat decentralized) earned a certain degree of competitiveness to other territories and, consequently, there were productive and consumption deconcentration to areas previously considered economically and socially depressed (SPOSITO, 2015). Deconcentration that also occurred due to the increase of the consumption power of the interior of Brazil (SILVEIRA, 2014). They also occurred frequently as of the opening of the economy, and the key factor was decreasing production costs through cheaper labor. The productive deconcentration an unquestionable determinant, since many spaces reaffirmed in central character, as the southern region of Brazil, in the production and processing of pork and poultry meat.

This process of geographical mobility of capital occurs most vehemently in the late 1970s, at the center of the capitalist system and, at the end of the 1980s, on the periphery of the system. In Brazil, this process was more intense from the 1990s. The processes of globalization of capital and/ or empire of capital, with innovations (more incremental and process than basic and product) in the transportation and logistics systems, with the reduction of customs barriers and the deregulation of the financial system, gave the capitals the liberation of local sources of power (BARAT, 2007). The processes of globalization of capital and/or empire of capital, with innovations (more incremental and process than basic and product) in the transportation and logistics systems, with the reduction of customs barriers and the deregulation of the financial system, gave the capitals the liberation of local power sources. The present time, expressed by the technical-scientific-informational means (SANTOS; SILVEIRA, 2008), places the entire society before a public productive model of consumption and geopolitics. Restructuring was necessary and the establishment of a novel archetype of circulation to extract the maximum value of transport systems and, especially, of corporate and state logistics. That is why the young instrument that joins the technical-scientific revolution is communication, because it is more comprehensive than information and contemplating it.

It is, in this orientation, that there are detachable transformations observed in the movement systems and their impacts on the territories, such as: 1) restructurings in city-port relations (MONIÉ; SILVA, 2003); 2) the amplitude of aerial flows and, preeminently, in medium and medium size cities, forming new airport hubs, reorienting the logic that privileged the centrality of certain spaces of the Brazilian urban network; 3) the formation of driving axes on high-traffic highways, often comprising "development axes" (SPOSITO, 2005), with a great economic flow, attracting economic activities and population, as well as a parallel major road axes. These changes are credible because they encompass infrastructures, means and organizational systems that facilitate territorial fluidity. They can be real because of the new configurations of the advance of the productive forces that demand, in Brazil, dense normative and tributary changes, that is, these transformations impel the relations of production to the maximum and force their readjustment. The remote spatial logics are replaced by new ones, more dynamic and capable of deep territorial transformations, especially when the national state has a structure of power girdled. 


\section{STATE AND CORPORATE LOGISTICS, INVESTMENTS, STANDARDS AND TAXATION IN BRAZIL}

Exclusively the use of new technologies and logistic strategies with the purpose of increasing the circulation are not satisfactory for the expansion of the economic flows by the territory. A system of rules and taxation that legally leads to the development of territorial fluidity is also imperative. The State, therefore, is basilar with respect to the strategies, the planning and the management of the territory. It is observed that in Brazil, State logistics, including massive investments in transport infrastructures, are territorially unequal, either by the performance of the federal government, the federal units, and the municipalities. See the event of the construction, expansion, duplication and concession of motorways in the Macrometropole Paulista (EMPLASA, 2015), aiming to meet great business demands for new subsidized spaces, with low soil value and with easy accessibility. In the Itajaí microregion, a port and logistics complex was installed, as a result of favorable natural conditions, public investments, subsidies (ICMS, ISS and others) and the presence of private capital with know-how in transportation, customs, storage and logistics. Still, we can highlight the Free Zone of Manaus and some grain-producing territories of the Midwest, which, due to lack of adequate infrastructure, use intermodality and/or modalities with high costs for the type of cargo transported, such a bulk grains.

The toll, a product of state logistics in association with business groups, is a surcharge that reaches various interests. In this sense, it is a significant example of state action through concession to private initiative. In addition, rates and circulation taxes (taxation) are spatially unequal, such as the ICMS and the ISS, as well as other subsidies from public sphere (even though ICMS has been equalized throughout the national territory, many states and municipalities return part of it to private companies as one of the elements of the fiscal war). The public investments and the installed legal and tax model, ${ }^{7}$ favorable to the private initiative, do not account for accepting the precisions of the productive forces installed to gain the aspirational fluidity to the territory. On the other hand, the archetypes of concessions, necessary for the expansion of fluidity, were deprived and contributed only to a portion of companies moving forward in the movement of cargoes and capitals. We highlight the increase in fluidity for goods of high value added, since these circulate readily by large toll motorways due to the ignoble increase in production costs.

Speculative and productive corporate demands, in full swing of "economic globalization" and "flexible accumulation regime," intervene in standards and taxation systems to operate more efficiently, in addition to demanding fixed tranportation, storage and communications public Power. Because these corporations are spatially selective, the lack of presence of the state in providing the territory with more "just" State logistics cooperates to widen territorial inequalities. The organizational strategies of corporations in logistics (corporate), on the other hand, allowed the increase of flows, and with State logistics controlled in part by corporations, led the territorial fluidity for a better circulation of capital.

An adequate system of regulation and taxation of circulation therefore tends to stimulate economic flows and interfere with the proper planning of the territory, which is largely aimed at corporate interests. The increase in the territorial fluidity to serve large capital would not be a problem if capital were not used to cause regional and local losses through spatial selectivity. This is established in the search for greater profits through intercapitalist competition and the exploitation of labor. More and more there is the dynamization of accurate spaces in the losses of others, solidifying or expanding the regional differentiations.

(7) A strong case that justifies this assertion is the discussion on tax reform, with emphasis on ICMS, for ISS, IPI, CIDE, COFINS, PIS, among others. The ICMS, for having a different calculation basis, until recently, for each federative state, acted in the circulation system, interfering differently in the spatial interactions. 


\section{ECONOMIC DYNAMICS AND TERRITORIAL IMPACTS OF FLUIDITY AND COMPETITIVENESS IN BRAZIL}

Brazil has comparative advantages in the production of grains, food and some industrial products. However, competitiveness is affected by the lack and inadequate conservation of transport and storage infrastructures and, therefore, by the lack of more operational state logistics, as well as by more innovative corporate logistics (both organizational and in demand for technologies) with more capital. In addition, effective standards and taxation systems make it impossible to achieve greater intermodal ${ }^{8}$ and multimodal articulation and, consequently, a higher territorial fluidity. The "Brazil transport cost", which varies widely regionally, is one of the highest in the world and is four times higher than "transportation costs in the United States".

However, the transport workforce and, consequently, the low profit of the transporters are favorable to Brazil. These elements are consequences of the high value added and services offered, respectively. In 2016, Brazil had a large number of autonomous truck drivers, as well as a large fleet of trucks, with 1,883,867 units and an average age of 10 years and 3 months (BRAZIL, 2017). It financed many transport equipment with interest below market, facilitating the acquisition of trucks by transport companies and freelancers (through FINAME), namely in the Lula da Silva government, slows down transporters' profits. This in addition to the high maintenance and circulation inhibits the renewal of the national fleet. A scenario, therefore, that maintains the high transport costs, but this fact is also linked to the predominance of the national transport matrix to the highways.

For a more compensated development, there is a need for industries and services related to the transport sector, such as the productive sector of transport equipment. The Brazilian railway industry produced more than 3,000 cars a year in the 1970s. However, in the face of the scrapping of the sector, in the Fernando Collor and Fernando Henrique Cardoso governments, both the railway network and railway industries were stagnant and privatized and denationalized, such as MAFERSA, which was contracted by the French company ALSTOM.

The transport matrix is based on highways and they are responsible for handling approximately $63 \%$ of total freight-kilometers and $96 \%$ of passenger kilometers (BRAZIL, 2017). Without the iron ore and grains transferred by the railways, the road modal reaches the movement of approximately $90 \%{ }^{9}$ (BRAZIL, 2017). Multimodal transport is still incipient, and only some companies are precariously pushing for multimodality, using intermodality in many cases. The railways have a slow pace of modernization, and the concession model was mistaken, since it created a monopoly both in the control and maintenance of the lines as in the operation of the transport. The highways responded better to the historical growth rate of Brazilian capitalism, which had to congregate the dispersed economic and population territories of a country of continental proportions. In the 1970s, transport investments surpassed 2 percent of GDP. In the 1990s, these investments remained far from the one-digit house, or rather, they ranged from 0.10 percent to 0.30 percent of GDP (BRAZIL, 2013). This was a projected stage of scrapping of transport infrastructures in the handling of corporate litigation (especially the speculative investment groups) that scrutinized the command of the public services under the command of the state companies. The best way was to scrap and slow the quality of public services, to provoke setbacks as to the effectiveness of state administration, and to lower bids in public service concession auctions to private enterprise (BIONDI, 2003). However, this corporate strategy was applied not only to public transport services, but also to telecommunications, energy production and distribution, among others.

(8) However, it is not only the "Brazilian Transport Costs" due to the fierce competition that the Brazilian products face in the international market, but also the subsidies of the competing countries, that is to say, there is a fiscal war, a territorial competitiveness in the world scope of which Brazil participates.

(9) Railways carry $90 \%$ of their cargo with only five products: iron ore, steel, cement, agricultural bulk and coal. The so-called general cargo is basically transported by truck. The railroads, by their history, do not form a national network, but regional networks little articulated. 
As a result, the decline in the quality of services, due to the low investments, since the $1980 \mathrm{~s}$, led to the advance of the number of accidents and the "Brazilian Transport Cost" for exports and for supplying the domestic market. Other examples are: 1) the exhaustion of financing mechanisms; 2) the dismantling of intelligence and planning nuclei, such as GEIPOT; and 3) disruption of the statistics generation process. These and other components for the control of strategic public services persisted with less intensity in the Lula da Silva government, with road concessions. The lack of a national strategic planning for macroeconomic development restricted the Brazilian economy's advance for more than two decades, and the concessions (and their due model) derived from a market imposition rather than a demand from society. Hence, the concessions were benevolent to the model of neoliberal economic restructuring, especially to large international corporations. They assumed part of the public services of the country, and many others used as a competitive factor the privilege of location/installation in the margins of the pedagogical infovias, with motorways, fiber optics and others. Most of the Brazilian GDP (Gross Domestic Product) is produced in the vicinity of the toll roads and, likewise, they circulate through them, demanding more private interests in their concession.

Bulk and containerization techniques for transfer and storage have revolutionized the handling and packing processes of the loads. These features have interfered even in the aerial mode. Also, the more complex logistic chains have agreed to use air transport more for goods with high added value per unit of weight and/or time requirements, such a cultural products, high technology, e-commerce and pharmaceutical industries. These import from the United States, Europe and Asia raw materials by the airport of Viracopos, Guarulhos and Manaus. However, a part of the entrance customs procedures in Brazil is done by both Infraero in the airports and by the CLIAs (Logistic and Industrial Customs Centers). An example is the CLIAs located in Santa Catarina (more specifically in the microregion of Itajaí), due to the differentiated taxes, receive loads from other airports for the customs process. Thus, the cargo, departs reefers, leaving Campinas (with a Customs Transit Dispatch - CTD) to Santa Catarina and returns to São Paulo for the pharmaceutical industries. All transportation in the national territory is effected by road. This means that there is insufficient air-to-road intermodality and is based more on tax subsidies than on reducing logistics and transport costs.

In addition, the increase in passenger traffic, especially in emerging countries, due to the increase in the middle classes and the low cost of airfare, also conditioned the development of regional air transport, with new large airport hubs (Campinas) and medium-sized ones (Ribeirão Preto, São José do Rio Preto, Londrina, Maringá, Uberlândia, Joinville, Chapecó, among others). Other factors that incited the air sector and propitiated its increase in the matrix of cargo and passenger transport are related: 1) the increase of the size of the aircraft and its greater unit capacity (wide-bodies); 2) the maximum efficiency of the engines (passenger-kilometer increase per liter of fuel); 3) the growth of labor productivity by the computerization of tasks; 4) better business performance of airlines; and 5) the expansion of innovations in the aeronautical industry and in the airport infrastructure.

Companies are increasingly working with inventories reduced by the Just in Time system, with faster turnaround in warehouses and thus requiring faster agility in the moves (optimizing is the key concept). This situation places transport as the frontier for the cooling of production costs. It is in this sense that logistics outlines contribute to reducing the gap between production time and working time (MARX, 2011b). The research by increasing the operational efficiency (compatibilizing time, cost and quality) via option for modal with less transit time, and costs become essential in both global and regional competition. ${ }^{10}$

Regarding the standards systems, there were significant variations, such as: 1) the creation of the MTO (Multimodal Transport Operator); 2) multimodality; 3) the customs post-office terminals; 4) customs clearance (simplified customs clearance); 5) the Brazilian aeronautics code (creating the

(10) The degradation of the road network can increase operational costs (up to 40\%) in fuel expenses (up to 60\%) and travel times (up to $100 \%$ ) (BARAT, 2007). 
cargo agent); 6) the regulation of air cargo agencies; 7) easing regulation of the airline sector; 8) the International Air Transport Association (IATA); (9) the conventions for the air sector (such as that of Warsaw in 1929 and that of Chicago in 1944) which provide for passenger rights and airspace sovereignty; 10) the registration and nationality of the aircraft and crew; and 11) airport services.

In Brazil, after the economic opening of the 1990s, significant setbacks occurred, mainly in the loss of public patrimony, but also noteworthy normative, tax and infrastructural advances, which stood out as of 2003 with the government of Luiz Inácio Lula da Silva. Even so, the concessions and their mistaken legislation, carried out under the Fernando Henrique Cardoso government, bore loss to the country, so far, irrecoverable. The improvements, important though they may have been, summed up some of the normative and tax changes that were more consistent with the productive forces, but still far from following the international competitive standards of logistics and transportation. This fact does not prevent Brazil from being competitive internationally in the agrindustrial and mineral sector, since other costs, such as capital and labor, compensate certain circulation costs, such as transportation, storage and logistics (land rent).

Innovations in logistics and transport have unleashed local sources of political and trade union power, higher labor costs, taxes attributed to the fiscal war, agglomeration diseconomies, or external diseconomies in large cities and metropolises. ${ }^{11}$ These innovations are appropriate to further relativize the relation of space and time, as well as coining new opportunities for capitalist accumulation (SILVEIRA, 2014). Thus, industrial agglomerations lost relative importance when they became affected by agglomeration diseconomies. Many economic sectors - confined by the past territorial division of labor - were given off for spatial relocations, in which new logics of "location" were established (earned by free trade), through diversified trade barriers, new patterns of consumption, and so many other subsidies resulting from the reorganization of the productive and the relations of production. In this context, a tension arises between spatial concentration and deconcentration of production, centralization and decentralization of management and capitals and greater mobility and geographic expansion of capital. The new, territorial organization of labor, especially, internationally was only possible due to the most recent logistics revolution.

As of the 1980s, the main characteristics of industrial production were transformed in the sense of horizontal integration of productive chains, thus, there was fragmentation of several tangible and intangible activities for space. These demanded a more competent logistic organization of transportation and communication to attract spatially long points. The dissociation between the manufacturer and the holder of the brand and/or technology, through complex outsourcing processes, forced geographically broader commercial relationships, to which big companies directed the production of their goods and services to China, as did Hering, Sony, Philips and Nike. Therefore, the move in the transport and logistics systems began to make the circulation of goods more efficient in space. Containers, intermodal and multimodal transport and just-in-time payment systems have contributed both to the cooling of the upstream and downstream storage areas, as well as decreasing the extensive lines of production, occurrences that show the optimization and varied uses of the space for private and corporate instances.

The production of goods and services exceeded the regional and national borders and constituted intricate productive chains that needed complex logistical, transport, warehousing and telecommunications chains for the movement of inputs and products (economic flows). The circulation system has been affected by acute modernization, in which it pushes the packaging, handling, stocking, transferring and moving goods to meet the new logics of the global competition. The new professional logistics service operations (Logistics Services Operators - OSLs) went on to use and plan the most efficient use of systems to increase productivity in transport, such as intermodality, combined transport and multimodal transport.

(11) One of the ways to ease agglomeration diseconomies is to use "city logistics", that is, strategy, planning and management in the transfer of loads from larger vehicles to smaller vehicles, which can easily move in the densest areas of the city. 
Logistics, through planning, was quoted for the removal of obstacles, physical, operational and institutional loopholes, rationalizing regulations, government controls, legislation and bureaucratic procedures (simplification of customs and movement processes). It increased the performance of the vehicles through the compatibilization of the infrastructures, which induces the investments in transport infrastructures, stocking and intermodal and customs terminals and information technology, developing unitization techniques. Logistics also helps in the demand for the development of technologies in transport systems and in the territorial planning. Therefore, it cooperates for all these aspects, but not part of any of them, since its particularity is to be a strategy, a planning, a form of gesture that wraps/wrecks all those elements. Logistics optimizes and consents in a more efficient way in circulation in space, and in addition to collaborating in the economic gains of corporations through the reduction of costs and increased competitiveness. Logistics substantially modifies geographic space through corporate, state and, even, individual actions. Thus, is made the production of geographic space.

\section{FINAL CONSIDERATIONS}

The contemporary economic restructuring - the implication of the "globalization of capital" and/or the "capital empire" - which attacks the Brazilian economy, has a relatively new component, but articulated, id is, a state logistics (oriented to territorial planning) and a corporate logistics that are presumed to be an extension, despite spatial selection, of fluidity and territorial competitiveness, alluding to reconfigurations/reorganizations of certain parcels of the national territory. In this context, there is a close relationship of complementarity and dissent between state logistics and corporate logistics that, therefore, have been selectively influencing the growth of fluidity and territorial competitiveness in portions of Brazil, highlighting the selective international capitalist demands and nationals associated with these. Public authority, operates more prone to the support of corporate demands for infrastructure. Today, companies, through corporate logistics, optimize the existing infrastructures to eliminate the lack of transport and warehousing infrastructures and, consequently, the respective impacts that they cause in the territorial organization.

For all these reasons there are strong impacts of state and corporate logistics in the reorganization of the Brazilian territory, except for fluidity and territorial competitiveness. The period of greatest intensity, when these elements advanced significantly, was after the economic opening of the 1990s and, more specifically, after the reinsertion of Brazil, in a more competitive way, in trade and in international relations and the rise of the domestic market, with the Lula da Silva government, starting in 2003. The Brazilian territory began to have more fluid and competitive spatial cuts, going through accelerated processes of modernization inserting itself more competitively in the international division of labor. The geographical expansion of capital for new areas of the Brazilian territory was extensive and extremely fast. And by all this, in the process of continuity and discontinuity, there remained relations of archaic production and work, roughness, the difference between the lower and upper circuits of the urban economy, widely seen in urban social conflicts, widened. Meanwhile, there was also wage increase, income, consumption and improvement in various economic and social indicators. Accomodations and the emergence of conflicts characterize the modernization of the "interior" of Brazil.

Thus, the logistic elements of the State in the provision of transport engineering systems, standards and taxation and corporate logistics, close to optimize transportation, warehousing and logistics services (customs, consolidation of cargo, handling of goods, packaging, among others), in the contemporary economic restructuring in Brazil, will potentiate the most competitive regions for the welcoming of the new needs of the external and internal markets associated. There were items involved like: 
1) the opening of the Brazilian economy, the largest insertion of the country in trade and international relations and the extension of the domestic market, in particular the most general provisions, for the organization of the Brazilian territory. In this sense, there was the adjustment of infrastructure and corporate innovations in the growth of circulation, transport and logistics services;

2) basilar elements used by the public power to adapt territories, selectively chosen, such as transport engineering systems, standards and taxation, such as the design of spreading territorial fluidity, id is, planning and developing a state logistics, colligating the Territories have a degree of effectiveness for competitiveness. In that phase, the approach is the state taxation as a space producer, supporting infrastructure, operating within norms and tributary principles to fuse fluidity and competitiveness to the privileged portions of the Brazilian territory. However, the appreciation of the Brazilian State is that there are elements and archetypes that can include other scales, such as the supranational and intranational ones, as in the case of IIRSA/COSIPLAN in the patagus of South America and the Mercosul, of the federative units and municipalities;

3) the evolution/modernization of transportation, warehousing and logistics services for the corporation agents in the Brazilian territory (national and foreign companies) from the opening of the 1990s, and especially from the Lula da Silva government. There has been progress in corporate logistics and its joining as state logistics, expanding the efficiency of commodity movement in economic flows and, for a second, of spatial interactions, fueling production of embedded spaces in the center-peripheral logic, however, as an extension of the degree of forward autonomy of the outer relations of the Lula da Silva government and of the new geopolitics and global geoeconomics. Corporate logistics, by competing in the optimization of transportation and warehousing costs, have also maximized transport systems, giving them maximum efficiency, greater movement for the transport lines, even with the expansion requirement of them;

4) determined/selective territories were more likely to increase the fluidity and territorial competitiveness than others in Brazil, the result of the more elaborate linkage between state logistics and corporate logistics. It is emphasized, by means of some case studies, changes in the territorial organization enthusiastically in search of competitive integration of the territories, such as in the Macrometropolis Paulista, the expansion areas of agronomy in the Center of the West, Northeast and North of Brazil, and portion of the coast of Santa Catarina (between Joinville and Florianópolis, extending less intensely to the municipality of Criciúma). It is the Product, overall, of the subsidies of transportation and warehouse engineering systems, planning and management of the state areas, corporate logistics, productive interests and international demands. The capital point was that case studies revealed the impacts caused by state and private erosion, on various scales, on certain territories, decreasing or expanding their inequalities. 


\section{BIBLIOGRAPHICAL REFERENCE}

ANFAVEA - Associação Nacional dos Fabricantes de Veículos Automotores. Dados estatísticos. Disponível em $<$ http://www.anfavea.com.br/tabelas.html $>$. Acesso dia 10 de junho de 2016.

ARRIGHI, Giovanni. O longo século XX. Rio de Janeiro: Contraponto; São Paulo: Editora da UNESP, 1996. BARAT, J. Logística e transporte no processo de globalização. São Paulo: Editora da UNESP, 2007.

BELLUZZO, Luiz G. O capital e suas metamorfoses. São Paulo: Editora da UNESP, 2013.

BIONDI, A. O Brasil Privatizado II: o assalto das privatizações continua. São Paulo: Perseu Abramo, 2003. BRASIL. Agência Nacional de Transportes Terrestres (ANTT). Ministério dos Transportes. Disponível em $<$ http://www.antt.gov.br>. Acesso em 20 de novembro de 2017.

BRASIL. Plano Nacional de Transportes e Logística. Centro Nacional de Excelência em Engenharia de Transportes (CENTRAN). Ministério dos Transportes e Ministério da Defesa. Disponível em $<$ http://www. centran.eb.br/plano_logistica.htm>. Acesso dia 03 de julho de 2013.

CASTILLO, R. Agricultura globalizada e logística nos cerrados brasileiros. In: SILVEIRA, Márcio R. (Org.). Circulação, transportes e logística: diferentes perspectivas. São Paulo: Outras Expressões, 2011, p. 331-354.

CHANDLER, Alfred. Ensaios para uma teoria histórica da grande empresa. São Paulo: FGV Ed., 1998.

CHEPTULIN, Alexandre. A dialética materialista. São Paulo: Alfa-Omega, 1982.

CHESNAIS, François. A mundialização do capital. São Paulo: Xamã, 1996.

EMPLASA. Empresa Paulista de Planejamento Metropolitano. Plano de ação da macropetrópole paulista 2013-2040. Secretaria da Casa Civil do Estado de São Paulo. São Paulo: Emplasa, 2015.

FELIPE JUNIOR, N. Circulação, transportes e logística no setor portuário e marítimo brasileiro. Vila Velha: Above, 2014.

FIESC - Federação das Indústrias de Santa Catarina. Disponível em: <http://www.fiesc.com.br/>. Acesso em 29 de novembro de 2017.

HARVEY, David. A condição pós-moderna. São Paulo: Loyola, 1992.

HARVEY, David. A produção capitalista do espaço. São Paulo: Annablume, 2006.

HIRST, P. Q.; THOMPSON, G. Globalization in question. Nova Jersey: Wiley-Blackwell, 1999.

KON, Anita. Economia de Serviços. Rio de Janeiro: Elsevier/Editora Campus, 2004.

MARX, K. Grundisse. São Paulo: Boitempo; Rio de Janeiro: Ed. UFRJ, 2011a.

MARX, Karl. O Capital (Livro 2, Vol. III). Rio de Janeiro: Civilização Brasileira, 2011b.

MONIÉ, F.; SILVA, G.(Orgs.). A mobilização produtiva dos territórios. Rio de Janeiro: DO\&D Ed., 2003. PORTER, Michael. Estratégia competitiva. Rio de Janeiro: Campus, 1986.

SANTA CATARINA. Secretaria de Estado da Fazenda. Disponível em: $<$ http://www.sef.sc.gov.br/>. Acesso em 28 de novembro de 2017.

SANTOS, Milton. A natureza do espaço. São Paulo: Hucitec, 1996.

SANTOS, Milton. Globalização em questão. Rio de Janeiro: Editora Record, 2001.

SANTOS, M.; SILVEIRA, M. L. Brasil. Rio de Janeiro: Editora Record, 2008.

SILVEIRA, Márcio R. (Org.). Circulação, transportes e logística. São Paulo: Outras Expressões, 2011.

SILVEIRA, Márcio R. Circulação, transportes e logística. In: SILVEIRA, M. R. (Org.). Circulação, transportes e logística no estado de São Paulo. Curitiba: Editora Appris, 2014, p. 11-34.

SILVEIRA, Márcio R. Infraestruturas e logística de transportes no processo de integração econômica e territorial. Revista Mercator, Fortaleza, v. 12, n. 2, p. 41-53, 2013. 
SILVEIRA, M. R.; COCCO, Rodrigo G. Basis for a materialist and dialectical approach to spatial interactions. Revista Terrae, Campinas, v. 8, p. 35-42, 2011.

SPOSITO, E. S. (Org.). O novo mapa da indústria no início do século XXI. São Paulo: Edi. UNESP, 2015. WOOD, Ellen M. O império do capital. Rio de Janeiro: Boitempo, 2014. 